Sains Malaysiana 49(11)(2020): 2689-2698

http://dx.doi.org/10.17576/jsm-2020-4911-08

\title{
Synthesis of Hydroxylated Polyisoprene-Graft-Polylactide Copolymer
}

(Sintesis Kopolimer Poliisoprena Terhidroksil-Cangkuk-Polilaktida)

\author{
Benjamin Neoh Di-Shen, Siti Fairus Mohd Yusoff, TAKeno Akiyoshi, TAKahashi Shinya \& Farah \\ HANNAN ANUAR*
}

\begin{abstract}
Polyisoprene (PI) has been widely used in many industries for decades. Many researches have reported that most significant weaknesses of polyisoprene are caused by unsaturated double bond $C=C$. The aim of this research was to synthesis and characterize a new copolymer utilizing the unsaturated double bond $C=C$ of polyisoprene. PI is first modified to form hydroxylated polyisoprene (PIOH). The absence of alkene proton peak in NMR spectrum of PIOH is a strong evidence that the unsaturation of PI has been reduced. After that, PIOH is subjected as an initiator for the ringopening polymerization of D, L-lactide in bulk condition to form hydroxylated polyisoprene-graft-polylactide copolymer (PI-g-PLA). The NMR spectrum of the new copolymer structure showed an unique peak at 4.09 ppm corresponding to methine proton of polyisoprene backbone adjacent to the PLA chains, indicating the grafting of D, L-lactide is successful to form PIOH-g-PLA. The average molecular weight, $M_{w}$ of PIOH-g-PLA was significantly increased compared to PIOH, from 38260 to 56870 according to GPC. The surface of PIOH-g-PLA displayed significantly higher wettability and hidrophilicity than polyisoprene with water contact angle of below $30^{\circ}$. This owes to the terminal hydroxyl groups of PLA chains that lead to the formation of hydrogen bonds. Thermal stability studies by TGA and DTG of PIOH-g-PLA indicated two thermal degradations at $T_{\max } 260$ and $392{ }^{\circ} \mathrm{C}$ corresponding to PLA side chains and PIOH backbone, respectively, with PIOH exhibiting highest thermal stability compared to PI and the graft copolymer.
\end{abstract}

Keywords: Graft copolymer; hydroxylated polyisoprene; polylactide; ring opening polymerization

\section{ABSTRAK}

Poliisoprena (PI) mempunyai kegunaan yang meluas dalam pelbagai industri. Kebanyakan laporan kajian menunjukkan bahawa kelemahan sifat poliisoprena adalah disebabkan ketidaktepuan ikatan ganda dua $C=C$ pada rantai poliisoprena. Kajian ini bertujuan untuk mensintesis dan mencirikan kopolimer baharu melalui tindak balas pada ikatan ganda dua tidak tepu $C=C$ poliisoprena. PI pada mulanya diubah suai untuk membentuk poliisoprena terhidroksil (PIOH). Kehilangan puncak hidrogen alkena dalam spektrum NMR PIOH merupakan bukti kukuh bahawa ketidaktepuan PI telah berkurangan. Kemudian, PIOH digunakan sebagai pemula bagi tindak balas pempolimeran buka gelang dalam keadaan pukal untuk menghasilkan kopolimer poliisoprena terhidroksil-cangkuk-polilaktida (PIOHg-PLA). Spektrum NMR struktur kopolimer baharu tersebut menunjukkan puncak unik pada 4.09 ppm yang ditetapkan kepada hidrogen metina rantai tulang belakang poliisoprena bersebelahan dengan rantai PLA, membuktikan bahawa cangkukan D,L-laktida berjaya membentuk PIOH-g-PLA. Berat purata berat molekul, M $M_{w}$ PIOH-g-PLA telah meningkat berbanding PIOH, daripada 38260 kepada 56870 seperti yang ditunjukkan melalui GPC. Sifat permukaan PIOH-g-PLA menunjukkan kebolehbasahan yang tinggi dan lebih hidrofilik dengan sudut sentuhan air kurang daripada $30^{\circ}$. Ini adalah kerana kumpulan berfungsi hidroksil hujung rantai PLA telah menyumbang kepada ikatan hidrogen. Pencirian kestabilan terma PIOH-g-PLA menggunakan TGA dan DTG menunjukkan dua penguraian terma pada $T_{\text {max }}$ 260 dan $392^{\circ} \mathrm{C}$ bagi rantai sisi PLA dan rantai tulang belakang PIOH masing-masing, dengan PIOH mempunyai kestabilan terma yang lebih tinggi berbanding PI dan kopolimer cangkuk.

Kata kunci: Kopolimer cangkuk; pempolimeran buka gelang; poliisoprena terhidroksil; polilaktida

\section{INTRODUCTION}

Natural rubber (NR) is an irreplaceable resource in modern day production industry. NR is used in manufacturing of more than 40,000 products which more than 400 are medical devices (Kind \& Hull 2012; Nampoothiri et al. 2010). The usage of NR has been steadily increasing throughout the years, from 7.32 million tons in 2010 to 14.01 million tons in 2018 worldwide (MRB 2018).

The need of NR steadily increases due to the good properties of the resulting material, such as strong elasticity, high molecular weight, high tensile strength, renewable, impact resistant, and abrasion resistant (Anon. 
2014; Bristow et al. 1969; Brosse et al. 2000; Hanhi et al. 2007; Kind \& Hull 2012; Pretula et al. 2016). NR is purified to obtain polyisoprene (PI) which is the particle of natural rubber that provides all these properties. PI is hard to be mimicked by synthetic materials.

Modification of PI has been conducted for more than 50 years, and the common modifications are hydroxylation (Azhar et al. 2017), chlorination (Paoprasert \& Chanroj 2017), dehydrogenation, microwave technique (Idris et al. 2019), grafting (Wongthong et al. 2013), oxidation (Zahari et al. 2018a), vulcanization, selfassembly polymerization (Caldas et al. 2020), blending (Ahmad et al. 2015; Hisham et al. 2011), epoxidation (Azhar et al. 2017), mastication, hydrogenation (Azhar et al. 2016; Yakubchik et al. 1962) and cyclization (Swartling et al. 2018). Most modifications focus on the unsaturation of PI. One of the significant weakness of $\mathrm{PI}$ is the unsaturated double bond $\mathrm{C}=\mathrm{C}$ that causes PI to be weak against weathering and heat. PI is also readily decomposed upon heating due to random chain scission. In some cases, researchers utilize the unsaturation of PI. In recent research, polyisoprene was blended with carbon black and low-density polyethylene to form shape memory composite by utilizing the unsaturated double bond $\mathrm{C}=\mathrm{C}$ of polyisoprene and polyethylene to form specific crosslink region and crystallized region (Xia et al. 2019).

As many modifications have been done over the years, most modifications focus on reducing the unsaturation of the double bond $\mathrm{C}=\mathrm{C}$ in $\mathrm{PI}$, which is one of the factors of low heat resistance of PI. In many previous studies, synthesized copolymers show the properties of both polymers, which further improve the material in being more competent in the industry. Thus, the aim of this research was to synthesize a copolymer using polyisoprene and other eco-friendly material, which is D,L-lactide to form a grafted copolymer. The graft polymerization will take place at the unsaturated double bond $\mathrm{C}=\mathrm{C}$, thus reducing the unsaturation of PI and producing a competent grafted copolymer.

Polyisoprene is used as the backbone chain of the copolymer and D,L-lactide is the grafting monomer. During graft polymerization, D,L-lactide is polymerized and forms poly-D,L-lactide (PDLLA). PDLLA is a widely researched material due to the properties of biodegradable, biocompatible, and renewable. This research is envisaged to achieve grafted copolymer of hydroxylated polyisoprene-graft-polylactide (PIOH-gPLA). Referring to some past research, it is expected that the synthesis of PIOH-g-PLA is successful (Azhar et al. 2017, 2016) and it is expected to inherit both PI and PLA's properties. The graft copolymerization is carried out by melt ring-opening polymerization of cyclic D,L-lactide using hydroxylated polyisoprene (PIOH) initiator with the presence of $\mathrm{Sn}(\mathrm{Oct})_{2}$ catalyst. Scheme 1 shows the reaction scheme of PIOH-g-PLA synthesis. PIOH-g-PLA is characterized in terms of structure, thermal properties, surface properties and molecular weight.

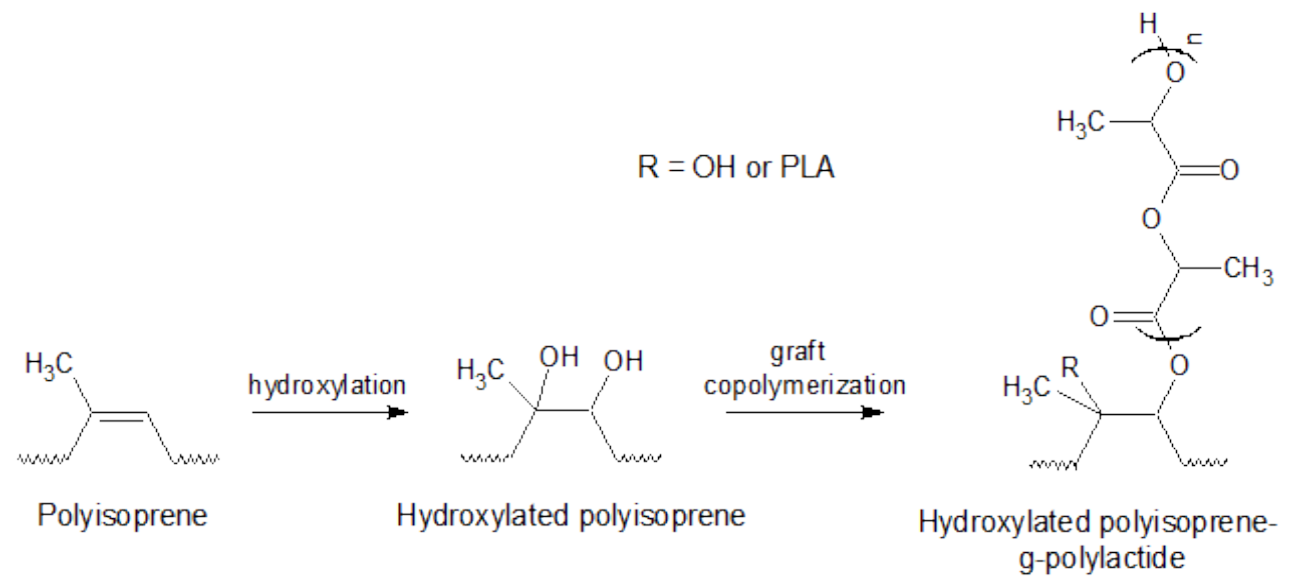

SCHEME 1. Reaction scheme of PIOH-g-PLA synthesis

\section{MATERIALS AND METHODS}

Hydrogen peroxide, $\mathrm{H}_{2} \mathrm{O}_{2}$, AR grade and methanol, $\mathrm{CH}_{3} \mathrm{OH}, \mathrm{AR}$ grade was purchased from R\&M Chemicals. Sodium tungstate dihydrate, $\mathrm{H}_{2} \mathrm{Na}_{2} \mathrm{O}_{6} \mathrm{~W}(\geq 99 \%)$ was purchased from Acros Organics (New Jersey, USA).
Acetic acid, $\mathrm{CH}_{3} \mathrm{COOH}(\geq 99 \%)$ was purchased from J.T Baker. Polyisoprene, $\mathrm{C}_{5} \mathrm{H}_{8}$, sodium carbonate, $\mathrm{Na}_{2} \mathrm{CO}_{3}$ ( $\geq 99 \%$ ), AR grade, D,L-lactide, $\mathrm{C}_{6} \mathrm{H}_{8} \mathrm{O}_{4}(99 \%)$ and tin(II) 2-ethylhexanoate, $\mathrm{C}_{16} \mathrm{H}_{30} \mathrm{O}_{4} \mathrm{Sn}(92.5$ - $100 \%)$ was purchased from Sigma Alrich (Germany). Toluene, $\mathrm{C}_{7} \mathrm{H}_{8}$, AR grade was purchased from Chemiz. 


\section{PREPARATION OF PIOH}

PIOH was synthesized following a previously reported method (Azhar et al. 2017), using epoxidation and oxidation via sodium tungstate complex. The polyisoprene samples were subjected to epoxidation and hydroxylation according to the previous outlined procedure with some modifications. Modifications are the use of polyisoprene instead of liquid natural rubber (LNR) solution and of the amount used. The amount used was modified from $17.0 \mathrm{~g}$ of LNR solution to $3.3 \mathrm{~g}$ of PI.

\section{PREPARATION OF PIOH-GRAFT-PLA}

The graft copolymer of PIOH-g-PLA was synthesized via ring opening polymerization of D,L-lactide in bulk using $\mathrm{PI}-\mathrm{OH}$ as initiator and $\mathrm{Sn}(\mathrm{Oct})_{2}$ as catalyst under nitrogen gas flow. PIOH ( $1 \mathrm{~g})$ and D,L-lactide ( $1 \mathrm{~g})$ were added into a Schlenk flask and the flask was heated at 120 ${ }^{\circ} \mathrm{C}$ in a silicone oil bath, followed by addition of $\mathrm{Sn}(\mathrm{Oct})_{2}$ $(41 \mu \mathrm{L})$ into the flask. The reaction was kept at $120{ }^{\circ} \mathrm{C}$ and constantly stirred for $6 \mathrm{~h}$. The flask was then left to cool down. The graft copolymer was transferred from the flask into a vial for characterization.

\section{CHARACTERIZATION}

PI, PIOH, and PIOH-g-PLA were each diluted in $\mathrm{CDCl}_{3}$ (15 $\mathrm{mg}$ in $460 \mu \mathrm{L}$ ) and analyzed by using Nuclear Magnetic Resonance Spectroscopy $\left({ }^{1} \mathrm{H}\right.$ and ${ }^{13} \mathrm{C}$ NMR) (JEOL, JNM-ECP 400, Japan) to identify the proton and carbon present after polymerization. Samples of $5 \mathrm{mg}$ in $5 \mathrm{~mL}$ THF were used for Gel Permeable Chromatography (GPC) (Waters/1515 Isocratic HPLC Pump equipped with a Waters 2414 Refractive Index detector, Waters Corporation, USA) with styragel type column, THF as solvent and polystyrene as calibrant with flow rate of 1 $\mathrm{mL} \min ^{-1}$ at $40{ }^{\circ} \mathrm{C}$ to determine number average molecular weight $\left(M_{n}\right)$, weight average molecular weight, $\left(M_{w}\right)$ and polydispersity index (PDI). Thermogravimetric Analysis (TGA) (Mettler Toledo, TGA/SDTA 851e) was used to determine the thermal stability of the prepolymers and graft copolymer using aluminum crucible, heated from 30 to $600{ }^{\circ} \mathrm{C}$ at the heating rate of $10{ }^{\circ} \mathrm{C} \mathrm{min}{ }^{-1}$ with constant flow of nitrogen gas. Static contact angle test was used to test the wettability of the surface of PIOH-g-PLA via film formation. A thin film of $10 \mathrm{wt}$. \% PIOH-g-PLA diluted in $\mathrm{CHCl}_{3}(1 \mathrm{~mL})$ were casted on glass and let dry for 3 days before static contact angle test (Contact Angle LSE-B100W).

\section{RESULTS AND DISCUSSION}

\section{HYDROXYLATED POLYIOSPRENE-GRAFT-POLYLACTIDE.}

Ring opening polymerization in bulk was employed in the preparation of PIOH-g-PLA. The catalyst, $\mathrm{Sn}(\mathrm{Oct})_{2}$ was added into the flask after both PIOH polymer D,Llactide monomer melted at $120{ }^{\circ} \mathrm{C}$. The addition of the catalyst initiates the ring opening polymerization of D,L-lactide to form poly-D,L-lactide (PLA). During the ROP of lactide, the first ring opened lactide is inserted between the oxygen and hydrogen atoms of the hydroxyl groups in PIOH repeating unit as shown in Scheme 2. This process repeats as subsequent lactides are inserted at the terminal hydroxyl to form PLA as the side chain of PIOH. This process is a grafting-from method and is a living polymerization.

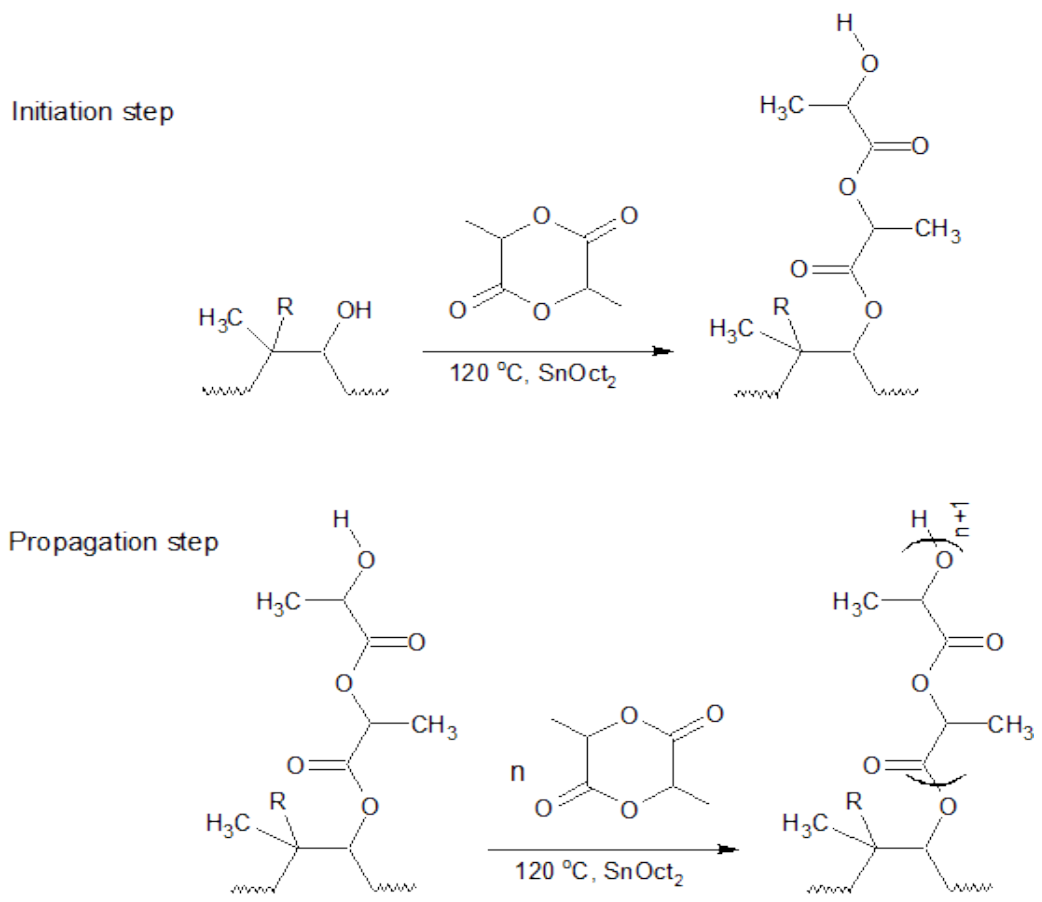

SCHEME 2. Grafting "from" living polymerization of PIOH-g-PLA graft copolymer 
MICROSTRUCTURE OF PIOH-GRAFT-PLA

Nuclear magnetic resonance spectroscopy (NMR) was used to determine the proton and carbon present in the microstructure of the synthesized graft copolymer. Figure 1 shows the NMR spectrum ( ${ }^{1} \mathrm{H}$ NMR) of the synthesized PIOH-g-PLA, whereas Table 1 shows the results extracted from Figure 1. As can be seen in Table 1, there are some important peaks that signifies the success of PIOH-g-PLA synthesis. The signal at chemical shift of 4.09 ppm belongs to the methine proton at the polyisoprene backbone, and is adjacent to PLA side chain. This signal is important as this proton was originally an alkene proton and first appeared at chemical shift of $5.19 \mathrm{ppm}$ in polyisoprene, which was determined by running ${ }^{1} \mathrm{H}$ NMR on the prepolymer polyisoprene and compared with other references (Azhar et al. 2016, 2017; Gemmer \& Golub 1979; Sato \& Tanaka 1979; Tanaka \& Sato 1976; Zell et al. 2002). After modifying polyisoprene to hydroxylated polyisoprene (PIOH), the proton shares its carbon with hydroxyl group and resonated at $3.42 \mathrm{ppm}$, which still can be seen in
Figure 1. The changes of chemical shifts are due to the shared carbon's deshielding effect towards the hydrogen in which this sudden change of environment affects the chemical shift (Azhar et al. 2017; Zell et al. 2002). The chemical shift of the proton in polyisoprene backbone becomes more deshielded when D,L-lactide inserted in between the hydrogen and oxygen atom of the hydroxyl group at $\mathrm{PIOH}$, causing a change in distortion of electron cloud. The change of chemical shift of this proton shows that the hydroxylated polyisoprene has successfully grafted with polylactide. The signal at 5.18 ppm shows the methine proton of the polylactide repeating units (Pretula et al. 2016; Rasal et al. 2010; Thakur et al. 1997a, 1997b; Zhong et al. 2002). The proton at the unsaturated double bond $\mathrm{C}=\mathrm{C}$ of polyisoprene starting material that initially observed at $5.05 \mathrm{ppm}$ was not observed in the PIOH-g-PLA copolymer product spectrum (Figure 1), indicating that after hydroxylation of polyisoprene, the double bound conversion was nearly $100 \%$ as the alkene peak cannot be detected in the ${ }^{1} \mathrm{H}$ NMR spectrum.

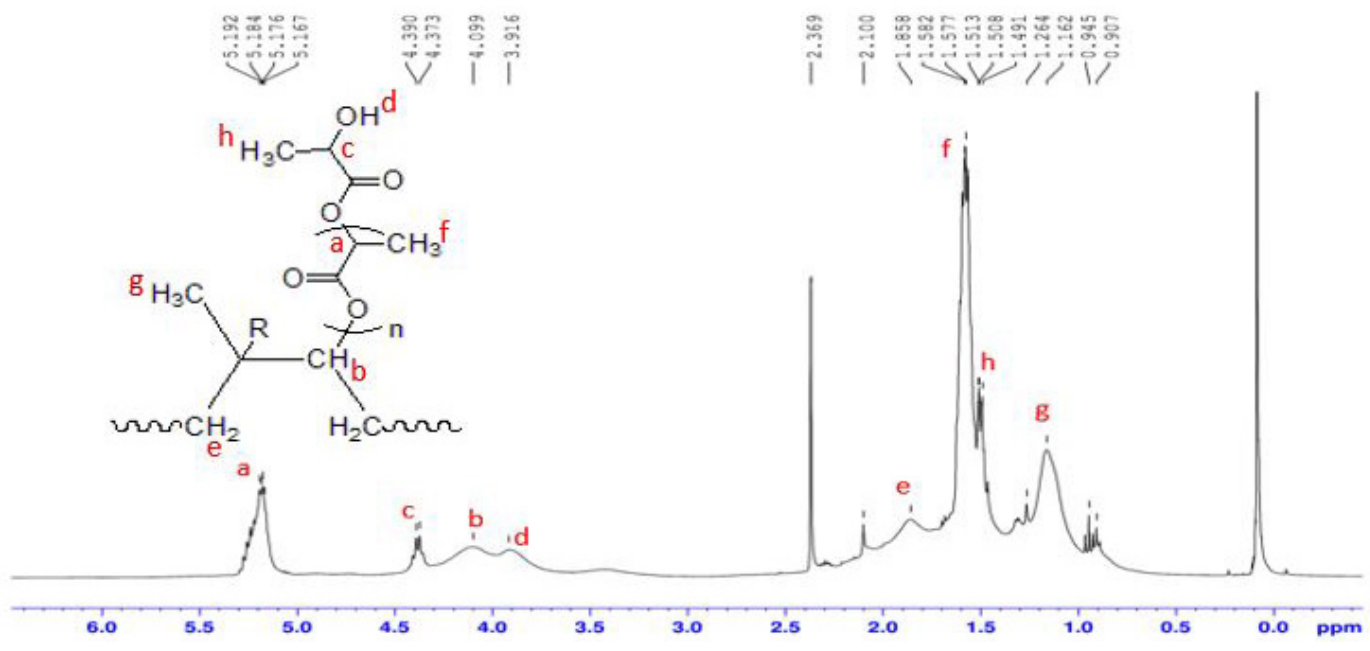

FIGURE 1. ${ }^{1} \mathrm{H}$ NMR spectrum of PIOH-g-PLA $\left(27^{\circ} \mathrm{C}, 400 \mathrm{MHz}, \mathrm{CDCl}_{3}\right.$ solvent)

TABLE $1 .{ }^{1} \mathrm{H}$ NMR data for PIOH-g-PLA

\begin{tabular}{|c|c|c|c|}
\hline Labelling & $\begin{array}{l}\text { Chemical shift } \\
(\mathrm{ppm})\end{array}$ & Type of proton & Assignment \\
\hline (a) & 5.19 & Methine proton of PLA repeating unit & $-\mathrm{CH}-$ \\
\hline (b) & 4.09 & Methine proton of PI backbone & $-\mathrm{C} \underline{\mathrm{H}}-$ \\
\hline (c) & 4.39 & Methine proton of PLA terminating unit & $-\mathrm{C} \underline{\mathrm{H}}-$ \\
\hline (d) & 3.91 & Hydroxyl proton of $\mathrm{OH}$ & $-\mathrm{OH}$ \\
\hline (e) & 1.85 & Methylene proton of PI backbone & $-\mathrm{CH}_{2}-$ \\
\hline (f) & 1.58 & Methyl group of PLA repeating unit & $-\mathrm{CH}_{3}$ \\
\hline (g) & 1.26 & Methyl group of PI backbone & $-\mathrm{CH}_{3}$ \\
\hline (h) & 1.49 & Methyl group of PLA terminating unit & $-\mathrm{CH}_{\underline{3}}$ \\
\hline
\end{tabular}


Figure 2 shows the ${ }^{13} \mathrm{C}$ NMR spectrum of PIOH-gPLA, whereas Table 2 shows the results extracted from Figure 2. The methine carbon at PI backbone appears at $129 \mathrm{ppm}$. Based on previous reports (Anancharoenwong 2011; Gemmer \& Golub 1978; Tanaka \& Sato 1976), all the peaks that appear on the ${ }^{13} \mathrm{C}$ NMR spectrum of PIOHg-PLA is accurate in comparison. The change in adjacent atom after the graft polymerization causes a change of the appearance of the methine carbon at PI backbone in the ${ }^{13} \mathrm{C}$ NMR spectrum.

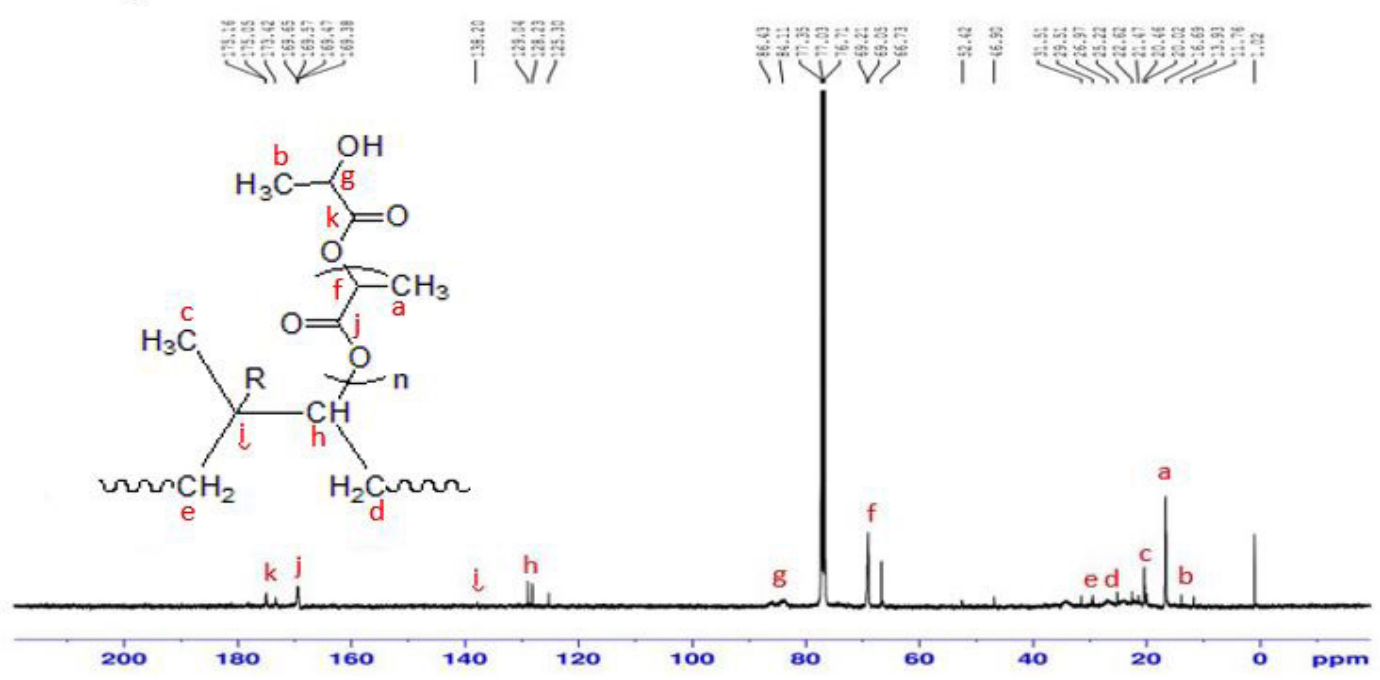

FIGURE 2. ${ }^{13} \mathrm{C}$ NMR spectrum of carbon atoms in PIOH-g-PLA

TABLE $2 .{ }^{13} \mathrm{C}$ NMR data for PIOH-g-PLA

\begin{tabular}{|c|c|c|c|}
\hline Labelling & $\begin{array}{l}\text { Chemical shift } \\
\text { (ppm) }\end{array}$ & Functional group & Type of carbon \\
\hline & $76-78$ & $\mathrm{CDCl}_{3}$ & \\
\hline a & 20 & Methyl carbon of PLA repeating unit & $-\mathrm{CH}_{3}$ \\
\hline $\mathrm{b}$ & 16 & Methyl carbon of the PLA terminating unit & $-\mathrm{CH}_{3}$ \\
\hline $\mathrm{c}$ & 26 & Methyl carbon of PI backbone & $-\mathrm{CH}_{3}-$ \\
\hline d & 29 & Methylene carbon of PI backbone & $-\mathrm{CH}_{2}-$ \\
\hline e & 31 & Methylene carbon of PI backbone & $-\underline{\mathrm{C}}_{2}-$ \\
\hline f & 69 & Chiral carbon of PLA repeating unit & $-\underline{\mathrm{C}}-$ \\
\hline $\mathrm{g}$ & 84 & Chiral carbon of PLA terminating unit & $-\underline{\mathrm{C}}-$ \\
\hline $\mathrm{h}$ & 129 & Methine carbon of PI backbone & $-\underline{\mathrm{C}} \mathrm{H}-$ \\
\hline $\mathrm{i}$ & 138 & Chiral carbon of PI backbone & $-\underline{C}-$ \\
\hline $\mathrm{j}$ & 169 & Ester carbon of PLA repeating unit & $-\underline{\mathrm{C}}=\mathrm{O}$ \\
\hline $\mathrm{k}$ & 175 & Ester carbon of PLA terminating unit & $-\underline{C}=\mathrm{O}$ \\
\hline
\end{tabular}




\section{THERMAL STABILITY OF PIOH-GRAFT-PLA}

Thermogravimetric analysis (TGA) was used to determine the thermal stability of PIOH-g-PLA, PI and PIOH. Figure 3 shows the thermogram of PIOH-g-PLA, PI and PIOH whereas Figure 4 shows the DTG curve of PI, PIOH and PIOH-g-PLA. Table 3 shows the tabulated results of Figures 3 and 4. Based on Table 3, PI started to decompose at $352{ }^{\circ} \mathrm{C}\left(\mathrm{T}_{\text {onset }}\right)$ and exhibited maximum decomposition temperature $\left(\mathrm{T}_{\text {max }}\right)$ at $382{ }^{\circ} \mathrm{C}$, whereas PIOH showed degradation at $\mathrm{T}_{\text {onset }}$ of $345^{\circ} \mathrm{C}$ and $\mathrm{T}_{\max }$ of $408{ }^{\circ} \mathrm{C}$. PIOH-g-PLA exhibited two degradation stages, with $\mathrm{T}_{\max }$ values of 260 and $392{ }^{\circ} \mathrm{C}$, respectively. The prepolymer PI underwent complete thermal degradation while PIOH and PIOH-g-PLA have residues of 4.9 and $10.0 \%$, due to the presence of tungsten and tin based catalysts used in the preparation of PIOH and PIOH-gPLA, respectively. The thermal stability increased after modification from PI to PIOH due to the removal of the unsaturated double bond $\mathrm{C}=\mathrm{C}$ via hydroxylation to form PIOH. For the graft copolymer PIOH-g-PLA, the overall thermal stability decreased compared to the intermediate prepolymer, PIOH. The first decomposition stage which belongs to polylactide graft segment whereas the second decomposition stage is the main polymer backbone. PLA has weaker thermal stability compared to PI, thus degrades earlier than PIOH backbone. PIOH-g-PLA which has

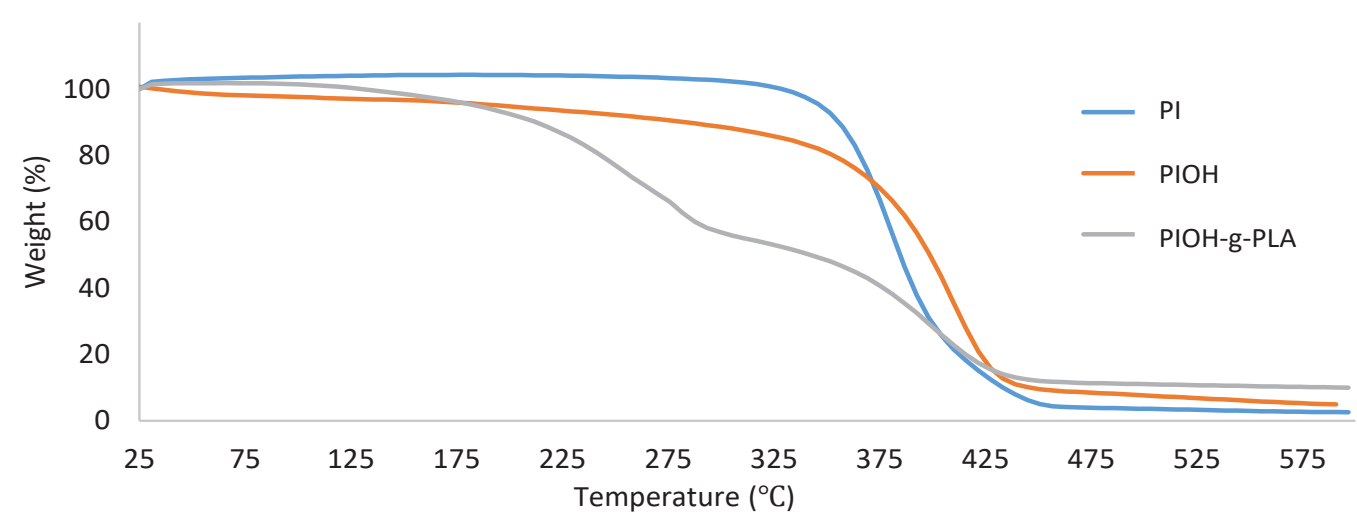

FIGURE 3. TGA thermograms of PI, PIOH and PIOH-g-PLA

50:50 weight ratio of $\mathrm{PIOH}$ and PLA during synthesis, decreases in weight by $48.0 \%$ after $330^{\circ} \mathrm{C}$. The molecular weight and D,L-isomer ratio in PLA affects the heat resistance of PLA. Research has shown that L-lactide have a stronger thermal stability than D-lactide when heated between 300 and $400{ }^{\circ} \mathrm{C}$ (Feng et al. 2018; Pluta 2004; Schmidt \& Hillmyer 2001). PLA can degrade via intra and intermolecular ester exchange resulting in the formation of $\mathrm{CO}_{2}, \mathrm{CO}$, acetaldehyde and methylketene (Kopinke et al. 1996). The polylactide in this research uses D,L-lactide as the monomer, thus having a lower thermal stability which result in a lower degradation temperature. Many researches have shown that the degradation temperature of PLA occurs at different temperature.

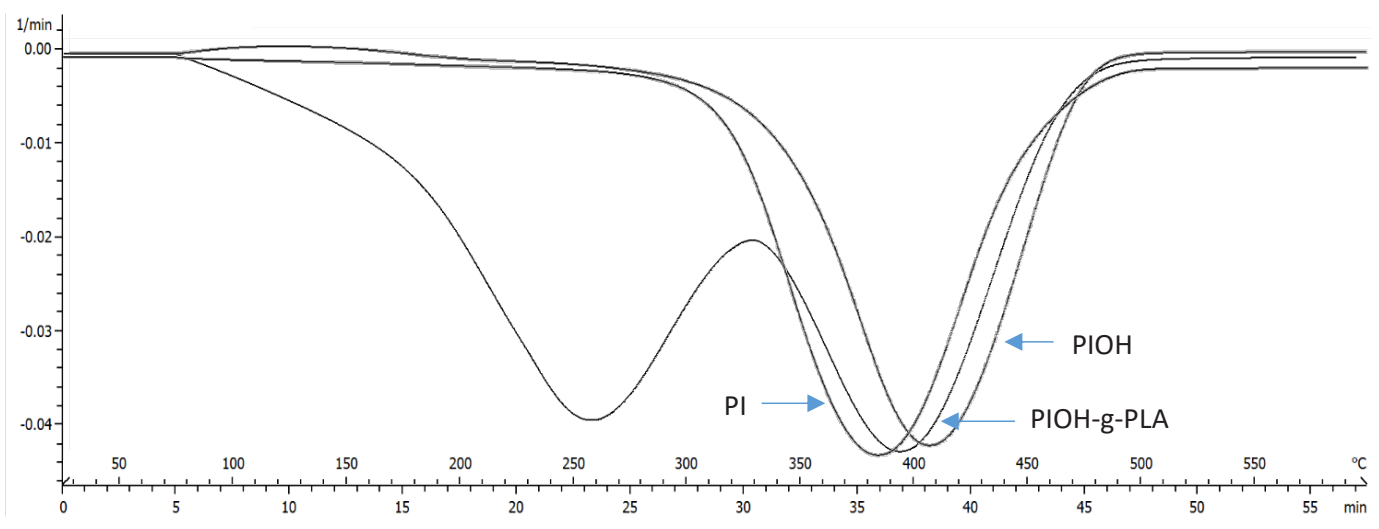

FIGURE 4. DTG curves of PI, PIOH, and PIOH-g-PLA 
TABLE 3. $\mathrm{T}_{\text {max }}, \mathrm{T}_{\text {onset }}, \mathrm{T}_{\text {end }}$ and residue of PI, PIOH, and PIOH-g-PLA

\begin{tabular}{|c|c|c|c|c|c|c|c|}
\hline Sample & \multicolumn{2}{|c|}{$\mathrm{T}_{\text {max }}\left({ }^{\circ} \mathrm{C}\right)$} & \multicolumn{2}{|c|}{$\mathrm{T}_{\text {onset }}\left({ }^{\circ} \mathrm{C}\right)$} & \multicolumn{2}{|c|}{$\mathrm{T}_{\text {end }}\left({ }^{\circ} \mathrm{C}\right)$} & Residue (\%) \\
\hline PI & \multicolumn{2}{|c|}{382} & \multicolumn{2}{|c|}{352} & \multicolumn{2}{|c|}{450} & 2.6 \\
\hline $\mathrm{PIOH}$ & \multicolumn{2}{|c|}{408} & \multicolumn{2}{|c|}{345} & \multicolumn{2}{|c|}{451} & 4.9 \\
\hline PIOH-g-PLA & 260 & 392 & 230 & N/A & $\mathrm{N} / \mathrm{A}$ & 445 & 10.0 \\
\hline
\end{tabular}

$\mathrm{N} / \mathrm{A}=$ cannot be observed due to overlapping of first and second thermal degradation

\section{MOLECULAR WEIGHT OF PIOH-GRAFT-PLA}

Gel permeation chromatography (GPC) was used to determine the molecular weight of PIOH-g-PLA and the prepolymers. In terms of number average of molecular weight $\left(M_{n}\right)$, weight average of molecular weight, $\left(M_{w}\right)$ and polydispersity index (PDI). Table 4 shows the results of analysis. Based on the table, it can be concluded that the overall molecular weight of PIOH-g-PLA is higher than the prepolymer PIOH. Because of the growing of polylactide chains on PIOH, the $\mathrm{M}_{\mathrm{w}}$ of PIOH-g-PLA shows significant increase, from $\mathrm{M}_{\mathrm{w}}$ of 38260 to 56870 . The increase of PDI is due to the limited control of the grafting mechanism. During the ring opening of D,Llactide, two hydroxyl groups of PIOH readily to form bond with D,L-lactide. The carbon grafting sites, which one contains methyl group and the other contains hydrogen atom, causes steric hindrance towards D,L-lactide to graft onto $\mathrm{PIOH}$. As the steric hindrance of the methyl group at PI backbone affects the grafting site of D,L-lactide, it also affects the grafting reactivity of D,L-lactide. This causes weight distribution along the chain to be broad and affects the PDI of PIOH-g-PLA copolymer. Besides that, as polyisoprene is readily decompose upon heating, this causes a phenomenon known as random chain scission (Kind \& Hull 2012) during copolymerization. Random chain scission starts to occur, targeting the 'weaker link'. This weaker links is formed due to remainders in PI and PIOH such as initiator, or some head-head repeating units during the formation of long polyisoprene chain via radical polymerization in natural latex (Gemmer \& Golub 1978; Kind \& Hull 2012; Zahari et al. 2018b). This further affects the $\mathrm{M}_{\mathrm{w}}$ of PIOH-g-PLA as during the synthesis of the graft copolymer, long duration of heat was applied. This is also one of the factors that causes the decrease in molecular weight from PI to PIOH.

TABLE 4. $\mathrm{M}_{\mathrm{n}}, \mathrm{M}_{\mathrm{w}}$, and PDI of PI, PIOH, and PIOH-g-PLA

\begin{tabular}{llll}
\hline Polymer & $\begin{array}{l}\text { Number average } \\
\text { molecular weight }\left(\mathrm{M}_{\mathrm{n}}\right)\end{array}$ & $\begin{array}{l}\text { Weight average } \\
\text { molecular weight } \\
\left(\mathrm{M}_{\mathrm{w}}\right)\end{array}$ & $\begin{array}{l}\text { Polydispersity } \\
\text { index (PDI) }\end{array}$ \\
\hline $\begin{array}{lll}\text { Polyisoprene (PI) } \\
\text { Hydroxylated polyisoprene (PIOH) }\end{array}$ & 4320 & 36220 & 22.3 \\
Hydroxylated polyisoprene-graft-polylactide & 2580 & 38260 & 14.9 \\
$\begin{array}{l}\text { (PIOH-g-PLA) } \\
\text { PIOH }\end{array}$ & 56870 & 40.3 \\
\hline
\end{tabular}

\section{SURFACE PROPERTIES OF PIOH-GRAFT-PLA}

Static contact angle test was used to determine the surface properties of PIOH-g-PLA. The sample was prepared using 10 wt. $\%$ of polymer diluted in chloroform and was left to dry for 3 days before characterized. Figure 5 shows the static contact angle plot where y-axis is angle of the droplet $\left(^{\circ}\right)$ and $\mathrm{x}$-axis is duration of the test (ms). According to Figure 5, there is a significant increase in wettability of PIOH-g-PLA copolymer compared to PI. Although polyisoprene and polylactide are hydrophobic 
polymers, previous research showed that the properties of terminating functional group and the molecular weight of the polymer affects the hydrophilicity of the material (Liu et al. 2010). The addition of hydrophilic functional group can increase the hydrophilicity of the polymer and that the shorter the length of the polymer, the more it increases the hydrophilicity of the material (Hassan et al. 2016; Kasalkova et al. 2015; Liu et al. 2010; Tretinnikov \& Ikada 1997). PI is hydrophobic due to the lack of functional groups to form hydrogen bonding with water. However, after modification into $\mathrm{PIOH}$, the addition of hydroxyl groups increases the hydrophilicity of $\mathrm{PIOH}$.
The PIOH-g-PLA copolymer is comprised of grafted PLA with hydroxyl group at one end, in addition to remaining hydroxylated polyisoprene backbone, further increases the amount of free carbonyl group and free hydroxyl group that can form hydrogen bonding with water. Therefore, the hydrophilicity of PIOH-g-PLA is high although both PI and PLA are hydrophobic material. The wettability of the surface of PIOH-g-PLA is high due to the addition of functional groups that can interact with water and form hydrogen bonding. Figure 6 shows the image obtained from static contact angel test at 0.5 and $25.5 \mathrm{~s}$ as a reference.

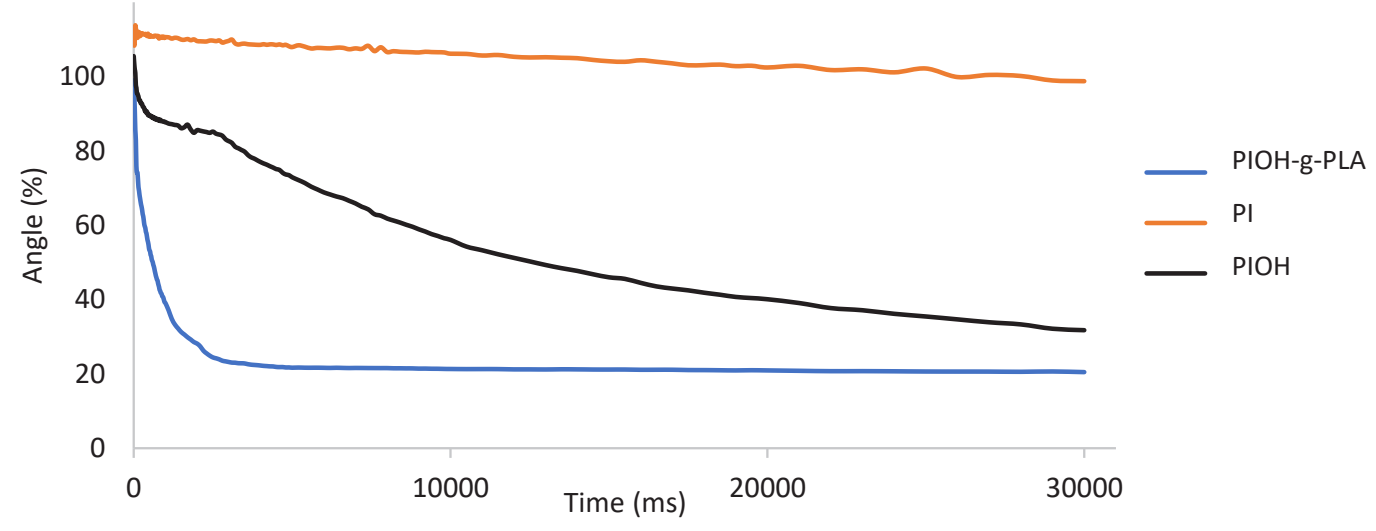

FIGURE 5. Static contact angle test plotted with angle $\left(^{\circ}\right)$ against time $(\mathrm{ms})$

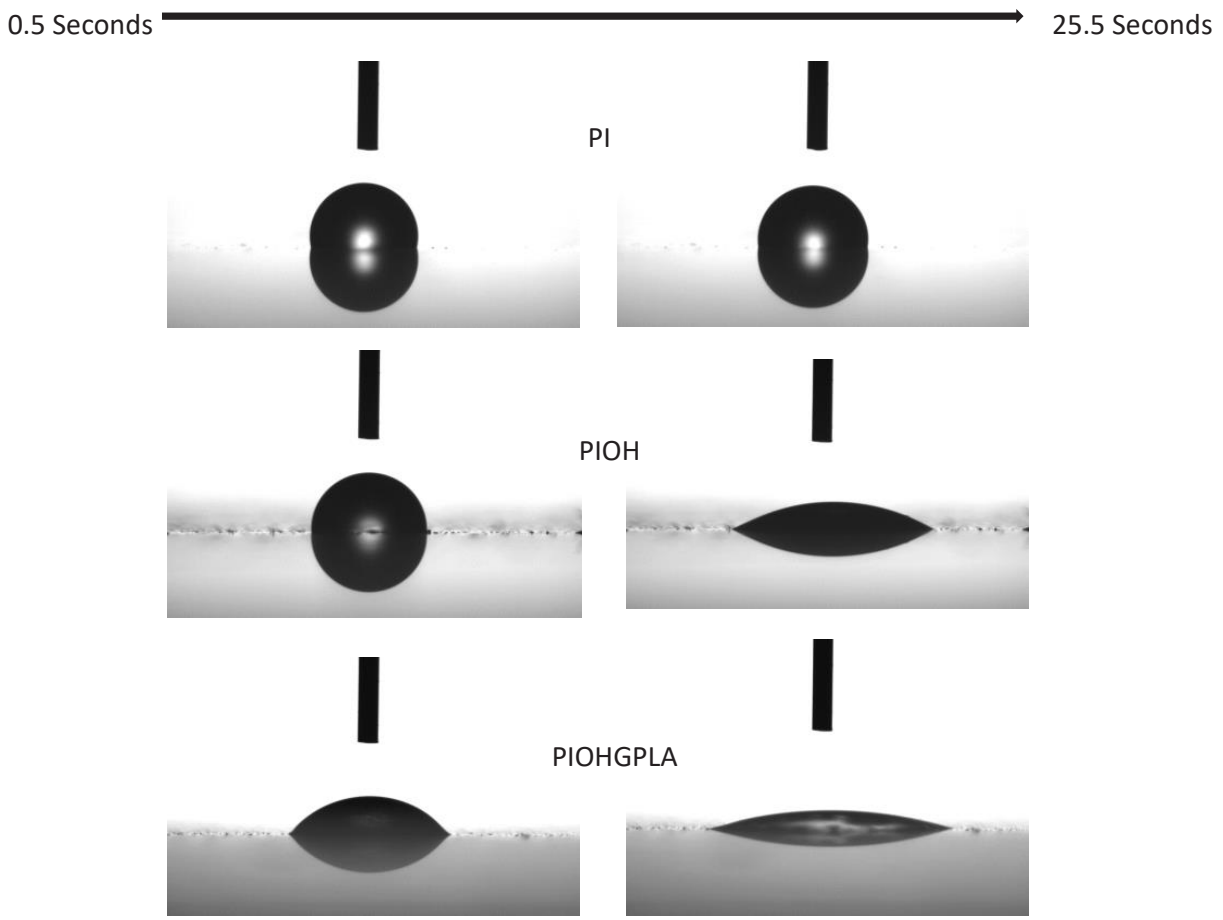

FIGURE 6. Image obtained from static contact angle test at 0.5 and $25.5 \mathrm{~s}$ for $\mathrm{PI}, \mathrm{PIOH}$, and PIOH-g-PLA 


\section{CONCLUSION}

The synthesis of PIOH-g-PLA was successful through the ring opening bulk polymerization of D,L-lactide with $\mathrm{PIOH}$ as initiator at reaction conditions of $120^{\circ} \mathrm{C}$ and 6 $\mathrm{h}$, yielding PIOH-g-PLA with interesting properties. The weight average molecular weight of PIOH-g-PLA was relatively high with values of 56870 due to the presence of PLA side chains, in comparison to 38260 for PIOH. The molecular weight distribution of PIOH-g-PLA was broad as the grafting mechanism was affected by the steric hindrance from the methyl group in $\mathrm{PIOH}$ and the occurrence of thermally induced random chain scission during copolymerization. The surface of PIOH-g-PLA shows hydrophilic properties, with contact angle of less than $30^{\circ}$ which contradicts PI and PLA hydrophobic characteristics. This was owed to the hydroxyl end group of PLA chains, allowing hydrogen bonding and improved surface wettability. The thermal stability of PIOH-g-PLA was relatively lower in comparison to PIOH and PI, with $\mathrm{T}_{\text {onset }}$ of 260,408 , and $382^{\circ} \mathrm{C}$, respectively, due to the presence of PLA. Overall, the unsaturation in PI was successfully modified to obtain PIOH and PIOHg-PLA with interesting properties. The unique advantage of PIOH-g-PLA synthesized using this method is that the material is solvent-free and using safe catalyst, making the copolymer potentially suitable in applications such as encapsulation material in drug delivery and as compatibilizer in biodegradable composites.

\section{ACKNOWLEDGEMENTS}

The authors would like to thank Universiti Kebangsaan Malaysia (UKM) and Gifu University (Japan) for providing analytical equipment used in this research. This work was supported by the Ministry of Education, Malaysia and Universiti Kebangsaan Malaysia under research grants FRGS/1/2019/STG01/UKM/02/8 and GUP2016-060.

\section{REFERENCES}

Ahmad, I., Ismail, H. \& Rashid, A. 2015. ENR-50 compatibilized natural rubber/recycled acrylonitrile-butadiene rubber blends. Sains Malaysiana 44(6): 835-842.

Anancharoenwong, E. 2011. Synthesis and characterization of cis-1,4-polyisoprene-based polyurethane coatings; study of their adhesive properties on metal surface. University of Maine, Ph.D. Thesis (Unpublished).

Anon. 2014. Preparation of Synthetic Polyisoprene Latex and Its Use in Coagulant Dipping. Kraton Performances Polymer Inc.

Azhar, N.H.A., Rasid, H.M. \& Yusoff, S.F.M. 2017. Epoxidation and hydroxylation of liquid natural rubber. Sains Malaysiana 46(3): 485-491.

Azhar, N.H.A., Rasid, H.M. \& Yusoff, S.F.M. 2016. Chemical modifications of liquid natural rubber. AIP Conference Proceedings 1784: 1-7.
Bristow, G.M., Campbell, J.M. \& Farlie, E.D. 1969. comparative properties of natural rubber and synthetic cis-polyisoprene. Journal Rubber Research Institute Malaya 22(2): 225-241.

Brosse, J.C., Campistron, I., Derouet, D., Hamdaoui, A.E., Houdayer, S., Reyx, D. \& Retoit-Gillier, S. 2000. Chemical modifications of polydiene elastomers: A survey and some recent results. Journal of Applied Polymer Science 78(8): 1461-1477.

Caldas, B.S., Danielle, L.B., Nakamura, C.V., Halila, S., Borsali, R. \& Muniz, E.C. 2020. Drug carrier systems made from self-assembled glyco-nanoparticles of maltoheptaose-bpolyisoprene enhanced the distribution and activity of curcumin against cancer cells. Journal of Molecular Liquids 309(2020): 113022-113031.

Feng, L., Feng, S., Bian, X., Gao, L. \& Chen, X. 2018. Pyrolysis mechanism of poly(lactic acid) for giving lactide under the catalysis of tin. Polymer Degradation and Stability 157: 212-223.

Gemmer, R.V. \& Golub, M.A. 1978. 13C NMR spectroscopic study of epoxidized 1,4-polyisoprene and 1,4-polybutadiene. Journal of Polymer Science: Polymer Chemistry Edition 16(11): 2985-2990.

Hanhi, K., Poikelispaa, H. \& Tirila, H.M. 2007. Elastometric materials. Plastic and Elastomer Technology: 1-84.

Hassan, M.I., Chong, L.H. \& Sultana, N. 2016. Wettability and water uptake properties of PLA and PCL/gelatin-based electrospun scaffolds. ARPN Journal of Engineering and Applied Sciences 11(23): 13604-13607.

Hisham, S.F., Ahmad, I., Daik, R. \& Ramli, A. 2011. Blends of LNR with unsaturated polyester resin from recycled PET: Comparison of mechanical properties and morphological analysis with the optimum blend by commercial resin. Sains Malaysiana 40(7): 729-735.

Idris, M.S.F., Yusoff, S.F.M. \& Mokhtar, W.N.A.W. 2019. New approach on the modification of liquid natural rubber production using microwave technique. Sains Malaysiana 48(7): 1433-1438.

Kasalkova, N.S., Slepicka, P., Kolska, Z. \& Svorcik, V. 2015. Wettability and Other Surface Properties of Modified Polymers. https://www.intechopen.com/books/wettingand-wettability/wettability-and-other-surface-properties-ofmodified-polymers.

Kind, D.J. \& Hull, T.R. 2012. A review of candidate fire retardants for polyisoprene. Polymer Degradation and Stability 97(3): 201-213.

Kopinke, F.D., Remmler, M. \& Mackenzie, K. 1996. thermal decomposition of biodegradable polyesters-i: poly $(\beta-$ hydroxybutyric acid). Polymer Degradation and Stability 52(1): 25-38.

Liu, C., Bonaccurso, E., Sokuler, M., Auernhammer, G.K. \& Butt, H.G. 2010. Dynamic Wetting of Polyisoprene Melts: Influence of the End Group. Langmuir 26(4): 2544-2549.

Malaysia Rubber Board (MRB). 2018. Natural Rubber Statistics 2018. Malaysia.

Nampoothiri, K., Nair, N.R. \& John, R.P. 2010. An overview of the recent developments in polylactide (PLA) research. Bioresource Technology 101(22): 8493-8501.

Paoprasert, P. \& Chanroj, T. 2016. Chlorohydrination of natural rubber latex using sodium hypochlorite for fuel- 
resistant materials. Rubber Chemistry and Technology 89(2): 251-261.

Pluta, M. 2004. Morphology and properties of polylactide modified by thermal treatment, filling with layered silicates and plasticization. Polymer 45(24): 8239-8251.

Pretula, J., Slomkowski, P. \& Penczek, P. 2016. Polylactides Methods of synthesis and characterization. Advanced Drug Delivery Reviews 107: 3-16.

Rasal, R.M., Janorkar, A.V. \& Hirt, D.E. 2010. Poly(lactic acid) modifications. Progress in Polymer Science 35(3): 338-356.

Sato, H. \& Tanaka, Y. 1979. 1H-NMR study of polyisoprenes. Journal of Polymer Science: Polymer Chemistry Edition 17(11): 3551-3558.

Schmidt, S.C. \& Hillmyer, M.A. 2001. Polylactide stereocomplex crystallites as nucleating agents for isotactic polylactide. Journal of Polymer Science, Part B: Polymer Physics 39(3): 300-313.

Swartling, D.J., Coonce, J.G. \& Cashman, D.J. 2018. Using balloons to model pi-conjugated systems and to teach frontier molecular orbital theory. World Journal of Chemical Education 6(2): 102-106.

Tanaka, Y. \& Sato, H. 1976. Sequence distribution of cis-1, 4-and trans-1, 4-units in polyisoprenes. Rubber Chemistry and Technology 49(5): 1269-1275.

Thakur, K.A.M., Kean, R.T., Hall, E.S., Doscotch, M.A. \& Munson, E.J. 1997a. A quantitative method for determination of lactide composition in poly(lactide) using H NMR. Analytical Chemistry 69(21): 4303-4309.

Thakur, K.A., Kean, R.T., Hall, E.S., Kolstad, J.J., Lindgren, T.A., Doscotch, M.A., Siepmann, J.I. \& Munson, E.J. 1997b. Highresolution ${ }^{13} \mathrm{C}$ and ${ }^{1} \mathrm{H}$ solution NMR study of poly(lactide). Macromolecules 30(8): 2422-2428.

Tretinnikov, O.N. \& Ikada, Y. 1997. Hydrogen bonding and wettability of surface-grafted organophosphate polymer. Macromolecules 30(4): 1086-1090.

Wongthong, P., Nakason, C., Pan, Q.M., Rempel, G.L. \& Kiatkamjornwong, S. 2013. Modification of deproteinized natural rubber via grafting polymerization with maleic anhydride. European Polymer Journal 49(12): 4035-4046.

Xia, L., Gao, H., Bi, W., Fu, W., Qiu, G. \& Xin, Z. 2019. Shape memory behavior of carbon black-reinforced trans-1, 4-polyisoprene and low-density polyethylene composites. Polymers 11(5): 807-815.

Yakubchik, A.I., Tichomirov, B.I. \& Sulimov, V.S. 1962. Hydrogenation of natural and synthetic cis-1,4polyisoprene. Rubber Chemistry and Technology 35(4): 1063-1065.
Zahari, N.W., Mohd, A.F., Samsuri, A. \& Kamarun, D. 2018a. Physical and mechanical properties of compounded hydroxylated natural rubber. AIP Conference Proceedings 1985: 040017.

Zahari, N.W., Mohd, A.F., Samsuri, A. \& Kamarun, D. 2018b. Thermal properties of hydroxylated natural rubber from in-situ hydroxylation process. AIP Conference Proceedings 1985: 040016.

Zell, M.T., Padden, B.E., Paterick, A.J., Thakur, K.A.M., Kean, R.T., Hillmyer, M.A. \& Munson, E.J. 2002. Unambiguous determination of the $13 \mathrm{C}$ and ${ }^{1} \mathrm{H}$ NMR stereosequence assignments of polylactide using high-resolution solution NMR spectroscopy. Macromolecules 35(20): 7700-7707.

Zhong, Z., Pieter, J.D. \& Jan, F. 2002. [(Salen)Al]-Mediated, controlled and stereoselective ring-opening polymerization of lactide in solution and without solvent: Synthesis of highly isotactic polylactide stereocopolymers from racemic D,L-lactide. Angewandte Chemie International Edition 41(23): 4510-4513.

Benjamin Neoh Di-Shen, Siti Fairus Mohd Yusoff \& Farah Hannan Anuar*

Department of Chemical Sciences

Faculty of Science and Technology

Universiti Kebangsaan Malaysia

43600 UKM Bangi, Selangor Darul Ehsan

Malaysia

Siti Fairus Mohd Yusoff \& Farah Hannan Anuar*

Polymer Research Center (PORCE)

Faculty of Science and Technology

Universiti Kebangsaan Malaysia

43600 UKM Bangi, Selangor Darul Ehsan

Malaysia

Takeno Akiyoshi \& Takahashi Shinya

Department of Chemistry and Biomolecular Science

Faculty of Engineering

Gifu University

Japan Tokai National Higher Education and Research System

1-1 Yanagido, Gifu-shi, Gifu, 501-1193

Japan

*Corresponding author; email: farahhannan@ukm.edu.my

Received: 3 December 2020

Accepted: 20 May 2020 